\title{
Back to School: Resources for an Uncertain Time
}

\author{
Daniel Forbes (University of Minnesota) \\ Kimberly Eddleston (Northeastern University) \\ David Deeds (University of St. Thomas)
}

KEYWORDS: Teaching Methods, Higher Education.

Colleges and universities everywhere are grappling with how to teach in fall of 2020. Courses are being offered in online, in-person, and hybrid formats, and many instructors find themselves having to change their formats just weeks before the start of the term. Fortunately, contributors to EIX and familybusiness.org (https://familybusiness.org/) have offered advice and tools that can help instructors adapt to the changing demands they face. We've assembled below a list of some of the key teaching resources you might like to know about.

\section{Effective Online Teaching}

Technology Tools for Working or Teaching Remotely

(https://eiexchange.com/content/technology-toolsfor-working-or-teaching-remotely)

We've all heard of Zoom by now. But have you heard of Slack, Calendly or Airtable?

\section{Design Remote Learning to Help Students Feel Connected \\ (https://familybusiness.org/content/design-remote- learning-to-help-students-feel-connected)}

Done right, online teaching can actually help students engage more with their professors and one another.

\section{Working From Home: Tips for Employees and Business Owners}

(https://eiexchange.com/content/working-from-hometips-for-employees-and-business-owners)

If you're still struggling with remote work, check out these best practices from Northeastern University professor Jay Mulki.

Professors Share Best Practices for the Online Classroom

(https://eiexchange.com/content/Professors-share -best-practices-for-the-online-

classroom?search=online\%20learning)

Advice from your peers about what works.

More Advice for Engaging Students Online (https://familybusiness.org/content/more-advicefor-engaging-students-online)

More tips that are easy to implement, from familybusiness.org board members

\section{Classroom Activities and Resources} Online Teaching Resources from EIX (https://eiexchange.com/content/online-teaching-resour ces-from-EIX?search=education\%20and\%20teaching)

Here are examples of videos and case studies that can be used as the basis for student reflections or discussions, as well as teaching tools that can be incorporated into online coursework.

Family Business Professors: Resources for Online Learning(https://familybusiness.org/content/family -business-professors-resources-for-onlinelearning)

This large collection of teaching exercises can work both in the traditional classroom and online.

Videos for the Global Family Business Community (https://familybusiness.org/content/videos-for-the-globalfamily-business-community)

These are challenging times for family businesses. These videos share best practices that help business owners and people who teach family business courses weather the crisis and manage what comes next.

\section{Inspirational Interviews}

eFest2018 Winner is Making Life More Colorful for 


\section{Diabetics}

(https://eiexchange.com/content/efest-2018-winner-ismaking-life-more-colorful-for-diabetics?search=efest)

Mission-Driven Startup Helps Abuse Survivors (https://eiexchange.com/content/mission-drivenstartup-helps-abuse-survivors?search=efest)

Park \& Diamond: eFest2017 Winner Ready to Launch(https://eiexchange.com/content/Park-andDiamond-efest2017-winner-ready-to-launch)

More Women Should Study Entrepreneurship (https://eiexchange.com/content/more-womenshould-study-entrepreneurship)

B-School Students Put New Restaurant on the Map(https://eiexchange.com/content/112-b-schoolstudents-put-new-restaurant-on-themap?search=)

A Father/Son Sitdown: Howard and Steven Aldrich (https://eiexchange.com/content/193-a-fathersonsitdown-howard-and-steven-aldrich)

Delivering the Goods: An Interview with Best Buy Founder Dick Schulze (https://eiexchange.com/content/6-delivering-the-g oods-an-interview-with-best-buy-and-eix-founderdick-schulze) 